\title{
Application of Nanotechnology to improve the performance of asphalt materials
}

\author{
Abdullah AbdelAleemAbou Khadrah, Mohamed Mostafa Elshrief, Marwa Mohamed Sabry.
}

\begin{abstract}
---
Nanotechnology has been gradually penetrated into the field of asphalt modification. Seemingly magic effects of nanomaterial have been brought to improve the performance of asphalt. To demonstrate many of the prospective applications, researchers have conducted a series of positive and effective efforts dealing with the preparation of modified asphalt to demonstrate the mechanism of modification and the resultant improvement in performance. In this review, various nanomaterial used in asphalt modification are initially presented, followed by the methods employed to modify the asphalt with these materials and finally the effects of nanomaterial on the performance of base asphalt are presented and the modification mechanisms are discussed. Based on the current research results, the influence of preparation process parameters on the compatibility of every phase in the modified bitumen and the stability of the modified asphalt system are described.

In this study the experimental testing of:

1- Nano silica with three percentages $2 \%, 4 \%$, and $6 \%$ by the weight of asphalt were blended in asphalt binder at high temperature to exfoliate the Nano silica within the asphalt.

2- Three types of Nano clay with different ratio aluminiumoxide (A, B, C) at $2 \%$ and $4 \%$ by the weight of asphalt were blended in asphalt binder
\end{abstract}

Dr. Abdullah AbdelAleem Abou Khadrah Faculty of engineering - Beni-suef University Egypt

Dr. Mohamed Mostafa Elsherif Faculty of engineering - Benha University Egypt

E, Marwa Mohamed Sabry Faculty of engineering - Benha University Egypt at high temperature to exfoliate the Nano clay within the asphalt.

It shows the difference of modified bitumen Viscosity, Penetration, Softening, flash point and Marshall

Stabilization showed in charts. These differences depend on the type of bitumen, the type of Nano material and the percent of additives. Using the results of these experiments to make a comparison between using Nanosilica and using Nano-clay with different percent we reached to the effects of each type and each percent of Nano material on the original bitumen properties so that the asphalt mix properties.

\section{Introduction}

Bitumen which extracted from petroleum sources didn't represents the case with standard specification to use it directly in pavement, so that there are many properties should be modified to be according to standard specifications.

\section{A. Asphalt materials:}

The chemical composition of asphalt is quite complex, therefore, researchers mainly use percentages of SARA (Saturates, Asphaltene, Resin and Aromatic) to compare various asphalt binder produced from different origins. Composition of each asphalt binder is typically grouped into two categories: asphaltenes and maltenes. The latter can be further subdivided into saturates, aromatics and resins [1].

\section{B. Nanotechnology and the current development in pavement materials:}

Nanotechnology is the creation of new materials, devices and systems at the molecular level as phenomena associated with atomic and molecular interactions 
strongly influence macroscopic material properties[3].Even though engineers are interested in material properties at the macro and miso scales, the Nano and micro scales provide fundamental insight for the development of science and technology. Although improvements in asphalt performance have been achieved through polymer modification, it will be interesting to explore what nanotechnology offers in improving asphalt pavement performance.

\section{Materials and Test Methods:}

This section will describe various materials used in this study as well as the sources of each material and its preparation method. The base asphalt used in this study was AC 60/70 Pen grade. Asphalt binder was then blended with $2 \%, 4 \%$ and $6 \%$ Nano- silica, Then using the same asphalt binder to blend it with three types with different ratio of aluminium oxide of Nano-clay at $2 \%$ and $4 \%$. The quantity of each additive was selected by weight of based asphalt binder. To conduct the mixing, an aluminum can was filled with $250-260 \mathrm{~g}$ of asphalt and placed in a thermoelectric heater. When the asphalt temperature reached to $150 \mathrm{o} \mathrm{C}$, specified amount of Nano- silica or Nano-clay was added to the can and mixing for two hours. Using this procedure one neat sample, Nano-silica modified asphalt (NSMA) samples and Nano-clay modified asphalt (NCMA) were produced. Ensure Nano-material particles are dispersed uniformly within the asphalt matrix.

\section{Laboratory testing and results:}

\section{A. Laboratory program design:}

The research team used the information gathered from the literature review and evaluations conducted to shape the direction of the laboratory program.

(1) The asphalt binder modified with $2 \%$ and $4 \%$ of first Nano clay (Nano clay A) by weight of asphalt binder.

(2) The asphalt binder modified with $2 \%$ and $4 \%$ of second Nano clay (Nano clay B) by weight of asphalt binder.

(3) The asphalt binder modified with $2 \%$ and $4 \%$ of Third
Nano clay (Nano clay C) by weight of asphalt binder.

(4) The asphalt binder modified with $2 \%$ and $4 \%$ and $6 \%$ of Nano-silica by weight of asphalt binder.

-ASTM C131 Standard Test Method for Resistance to Degradation of Small Size Coarse Aggregate by Abrasion, Impact in Los Angeles Machine and sieve analysis.

-Viscosity Grade bitumen's are specified by the methods described in ASTM Standard Viscosity test applied according to (AASHTO_T201-10). Viscosity Graded specifications covers bitumen (asphalt) graded by Viscosity at $60 \mathrm{C}\left(140^{\circ} \mathrm{F}\right)$.

-Penetration test (Rheological properties) of asphalt binder using penetration test according to

(AASHTO_T49-07).

-Softening point test according to (AASHTO_T53-09)

-Flash point test according to (AASHTO T 73 and ASTM D 93).

-Marshall TEST according to (AASHTO_T48-06).

\section{B. Experimental results and analysis:}

\section{B.1. Aggregate tests:}

To make sure that this aggregate can be used in the asphalt mix or not; it should apply aggregate tests. -ASTM C131 Standard Test Method for Resistance to Degradation of Small Size Coarse Aggregate by Abrasion, Impact in the Los Angeles Machine and sieve analysis test.

\section{B.2. Bitumen and asphalt mix test:}

Coverage of test procedures related to the characteristics of bitumen and asphalt mixes and finished asphalt pavements. Tests include measurement and evaluation of bitumen and asphalt mix performance. The viscosity, penetration, softening, flash point of bitumen improved and Marshall Test of asphalt mix improved by adding Nano silica and Nano clay with different ratios. 
Proc. of the Fourth Intl. Conf. Advances in Civil, Structural and Mechanical Engineering- CSM 2016

Copyright (C) Institute of Research Engineers and Doctors, USA .All rights reserved.

ISBN: 978-1-63248-093-4 doi: 10.15224/ 978-1-63248-093-4-21

\section{c. Experimental results and analysis:}

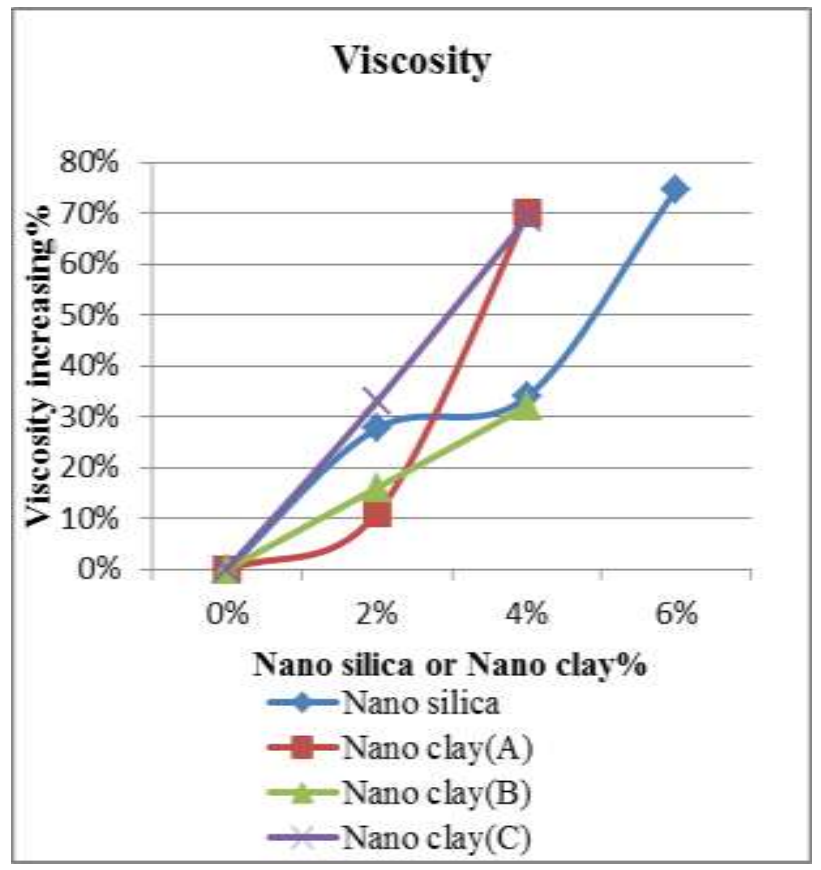

Chart (1)

Chart (1): Effect of adding Nano silica or Nano clay on Viscosity.

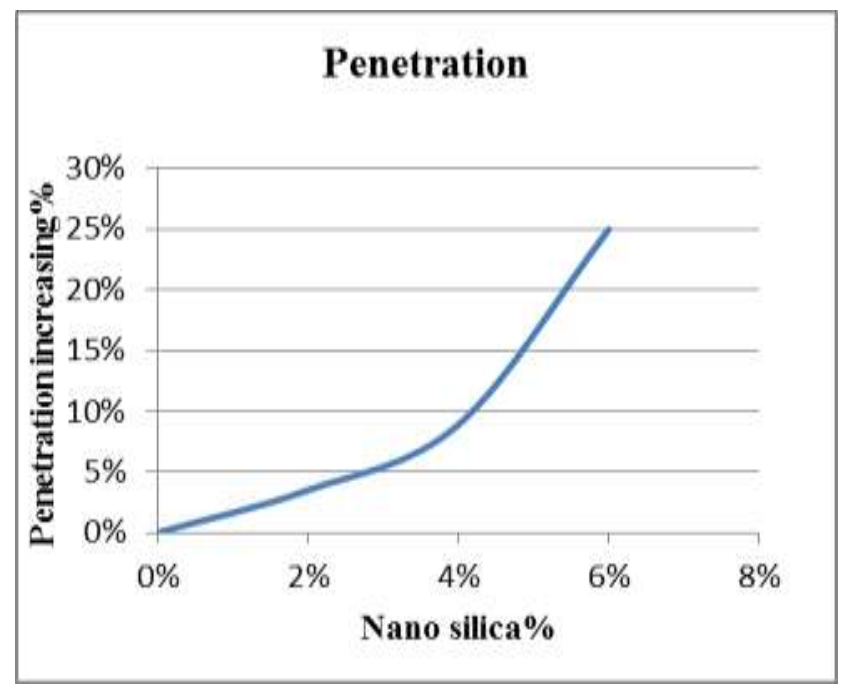

Chart (2)

Charts (2): Effect of using Nano silica on Penetration.

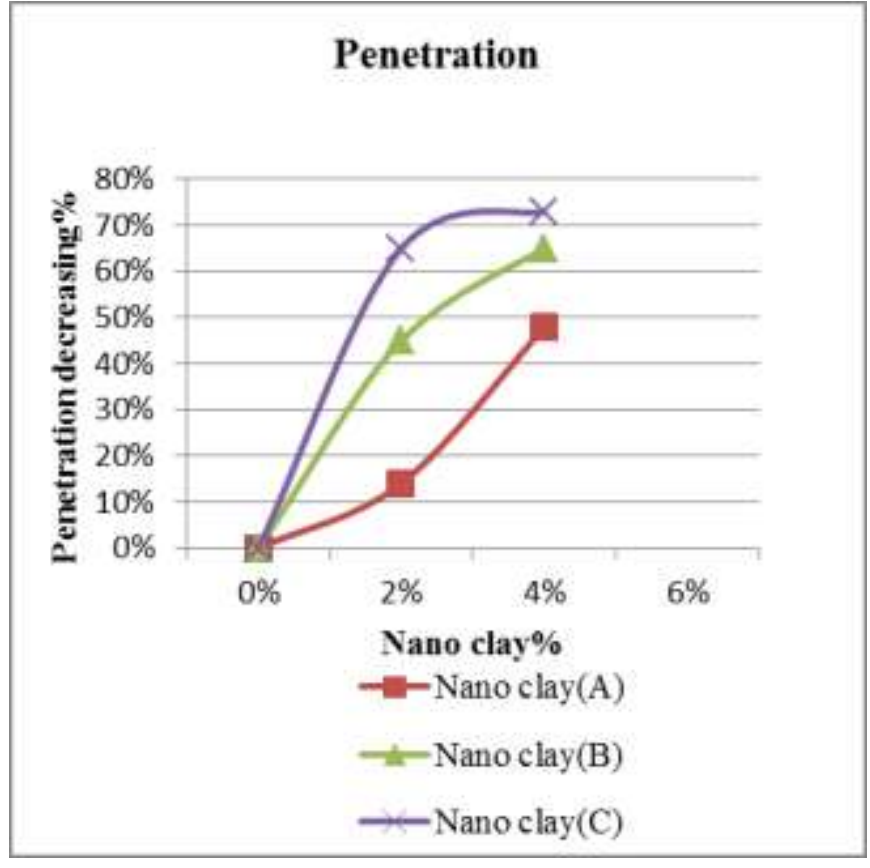

Chart (3)

Charts (3): Effect of using Nano clay on Penetration.

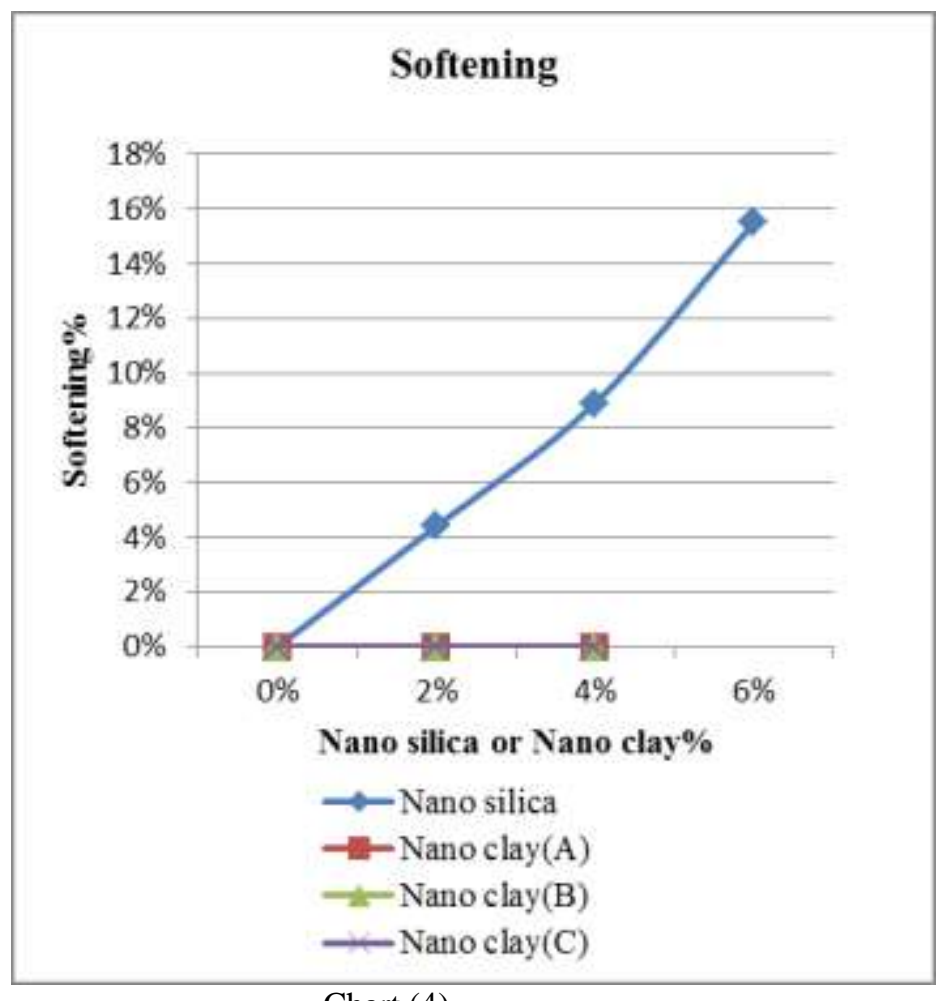

Chart (4)

Chart (3): Effect of adding Nano silica or Nano clay on softening, In case of adding Nano silica it increased but not affected by Nano clay. 
Proc. of the Fourth Intl. Conf. Advances in Civil, Structural and Mechanical Engineering- CSM 2016

Copyright (C) Institute of Research Engineers and Doctors, USA .All rights reserved.

ISBN: 978-1-63248-093-4 doi: 10.15224/ 978-1-63248-093-4-21

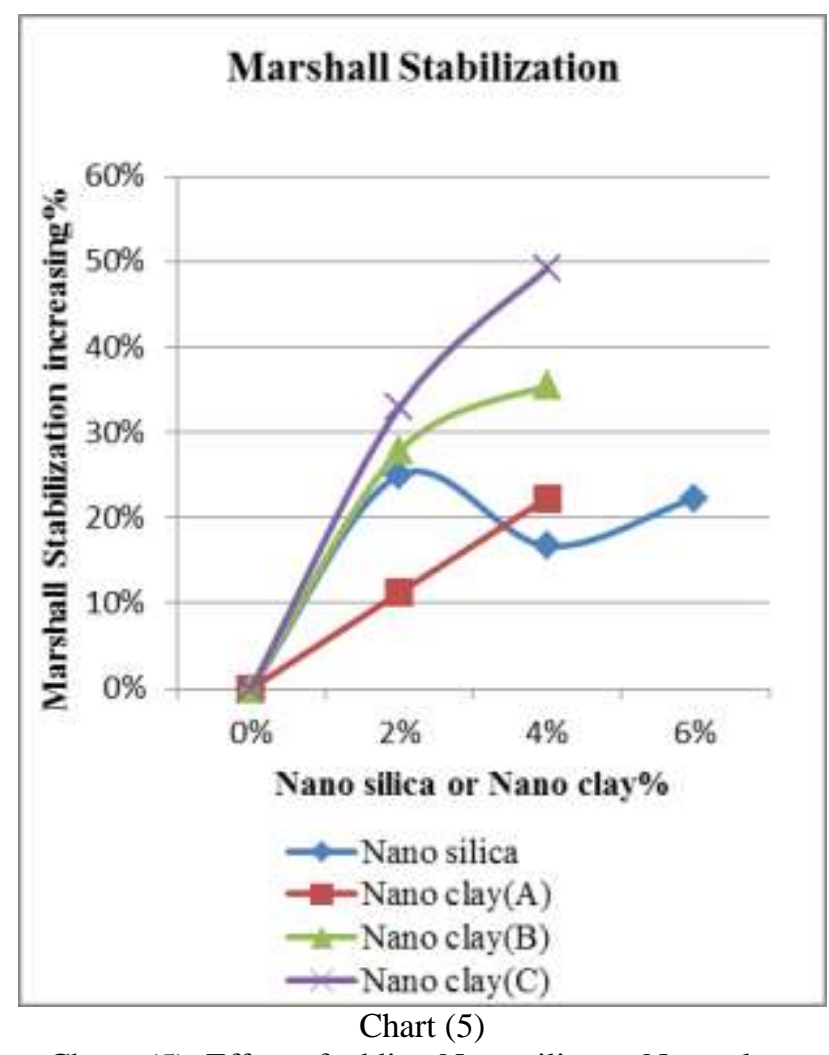

Charts (5): Effect of adding Nano silica or Nano clay on Marshall Stabilization.
Every chart shows the effect of adding each type and percent of Nano silica or Nano clay on one property of bitumen and asphalt (increasing or decreasing). These properties affected also by the chemical composition of original sample (Saturates, Asphaltene, Resin and Aromatic). The types of additives:

1- one type of Nano-silica was added at $2 \%, 4 \%$ and $6 \%$. 2-Three types of Nano-clay with different ratio of aluminium oxide (A, B, C) which added at $2 \%$ and $4 \%$.

\section{Conclusion:}

\begin{tabular}{|c|c|c|c|c|c|c|c|c|c|}
\hline \multirow{3}{*}{$\begin{array}{c}\text { Type of } \\
\text { additives } \\
\text { Additives\% }\end{array}$} & \multirow{2}{*}{\multicolumn{3}{|c|}{ Nano-silica }} & \multicolumn{6}{|c|}{ Nano-clay } \\
\hline & & & & \multicolumn{2}{|c|}{$\mathrm{A}$} & \multicolumn{2}{|c|}{ B } & \multicolumn{2}{|c|}{$\mathrm{C}$} \\
\hline & $2 \%$ & $4 \%$ & $6 \%$ & $2 \%$ & $4 \%$ & $2 \%$ & $4 \%$ & $2 \%$ & $4 \%$ \\
\hline viscosity & $\begin{array}{c}\text { Increase } \\
27.7 \% \\
\end{array}$ & $\begin{array}{c}\text { Increase } \\
33.9 \%\end{array}$ & $\begin{array}{c}\text { Increase } \\
74.8 \% \\
\end{array}$ & $\begin{array}{c}\text { Increase } \\
11 \% \\
\end{array}$ & $\begin{array}{c}\text { Increase } \\
70 \% \\
\end{array}$ & $\begin{array}{c}\text { Increase } \\
16 \% \\
\end{array}$ & $\begin{array}{c}\text { Increase } \\
32 \% \\
\end{array}$ & $\begin{array}{c}\text { Increase } \\
33 \% \\
\end{array}$ & $\begin{array}{c}\text { Increase } \\
69 \%\end{array}$ \\
\hline penetration & $\begin{array}{c}\text { Increase } \\
3.5 \%\end{array}$ & $\begin{array}{c}\text { Increase } \\
8.9 \% \\
\end{array}$ & $\begin{array}{c}\text { Increase } \\
25 \%\end{array}$ & $\begin{array}{c}\text { Decrease } \\
14 \%\end{array}$ & $\begin{array}{c}\text { Decrease } \\
48 \%\end{array}$ & $\begin{array}{c}\text { Decrease } \\
45 \%\end{array}$ & $\begin{array}{c}\text { Decrease } \\
65 \%\end{array}$ & $\begin{array}{c}\text { Decrease } \\
65 \%\end{array}$ & $\begin{array}{c}\text { Decrease } \\
73 \%\end{array}$ \\
\hline softening & $\begin{array}{c}\text { Increase } \\
4.4 \%\end{array}$ & $\begin{array}{c}\text { Increase } \\
8.9 \%\end{array}$ & $\begin{array}{c}\text { Increase } \\
15.5 \%\end{array}$ & & & Not & ected & & \\
\hline Flash point & & & & & Not affecte & & & & \\
\hline $\begin{array}{c}\text { Marshall } \\
\text { Stabilization }\end{array}$ & $\begin{array}{c}\text { Increase } \\
25 \%\end{array}$ & $\begin{array}{c}\text { Increase } \\
16.7 \%\end{array}$ & $\begin{array}{c}\text { Increase } \\
22.3 \%\end{array}$ & $\begin{array}{c}\text { Increase } \\
11.2 \% \\
\end{array}$ & $\begin{array}{c}\text { Increase } \\
22.3 \%\end{array}$ & $\begin{array}{c}\text { Increase } \\
27.8 \%\end{array}$ & $\begin{array}{c}\text { Increase } \\
35.5 \%\end{array}$ & $\begin{array}{c}\text { Increase } \\
32.9 \%\end{array}$ & $\begin{array}{c}\text { Increase } \\
49.2 \%\end{array}$ \\
\hline
\end{tabular}

-Viscosity of bitumen increased after adding Nano silica or Nano clay.

-Penetration of bitumen increased after adding Nano silica but decreased after adding three types of Nano clay.

-Softening of bitumen increased after adding Nano silica but not affected by adding Nano clay.

-Flash point of bitumen not affected in two cases.

-Marshall Stabilization of asphalt mix also increased after adding Nano silica or Nano clay.
The main objective of this research not to determine the best type of additives; because the results of tests depending not only on the type of additives but also the chemical composition of the bitumen sample. So the research explains the effect of each additives and percent of Nano silica or Nano clay on the bitumen sample and asphalt mix which we use. 
Proc. of the Fourth Intl. Conf. Advances in Civil, Structural and Mechanical Engineering- CSM 2016

Copyright $(\odot$ Institute of Research Engineers and Doctors, USA .All rights reserved.

ISBN: 978-1-63248-093-4 doi: 10.15224/ 978-1-63248-093-4-21

\section{References:}

[1] Petersen, J. C. (1984). " Chemical composition of asphalt as related to asphalt durability: state of the art." Transportation Research Record, 13-30.

[2] NAPA, National asphalt roadmap: a commitment to the future. Lanham, MD: National Asphalt Pavement Association; 2007.

[3] Chong KP. Nanotechnology and information technology in civil engineering. Confrence proceeding- towards a vision for information technology in civil engineering. In : lan Flood editor. 4th joint international symposium on information technology in civi engineering, November 15-16,2003,Nashville, TN, USA; 2004. P. 1-9.

[4] Ferhad Zafari, Mohammad Rahi, Nazanin Moshtagh, Hossien Nazockdast. The improvement of Bitumen Properties by adding Nano silica. Study of civil Engineering and Architecture (SCEA) volume3, 2014.

[5] Lu, X., and Isacsson, U. (1998). "Chemical and rheological evaluation 248 of ageing properties of SBS polymer modified bitumen's." Fuel, 77(9-10), 961-972.

[6] Lu, X., and Isacsson, U. (2002). "Effect of ageing on bitumen chemistry and rheology."construction and building materials, 16(1), 15-22.

[7] Gawel, I., and Baginska, K. (2004). "Effect of Chemical Nature on the Susceptibility of Asphalt to Aging." Petroleum Science and Technology, 22(9-10), 1261-1271.

[8] You, Z., Mills-Beale, J., Foley, J. M., Roy, S., Odegard, G. M., Dai, Q., and Goh, S. W. (2011). "Nano clay-modified asphalt materials: Preparation and characterization." construction and building materials", 25(2), 1072-1078.

[9] Yao, H., You, Z., Li, L., Shi, X., Goh, S. W., Mills-Beale, J., and Wingard, D. (2012b). "Performance of asphalt binder blended with non-modified and polymer-modified Nano clay". Construction and building materials, 35(0), 159-170.

[10] Birgisson B. Roadmap for research. presentation on the NSF workshop on nanomodification of cementitious materials at the university of Florida in August 2006; and personal communication; 2006.

[11]Balaguru PN. Nanotechnology and concrete: background, opportunities and challenges. Dundee, Scotland, United Kingdom: Thomas Telford services Ltd.; 2005.

[12] Colston SL et al. Functional micro-concrete: the incorporation of zeolites and inorganic nano-particles into cement micro-structures. J Mater Sci Lett 2000;19(12):1085-8.
[13]Roberts FL et al. Hot mix asphalt materials, mixture design and construction, 2nd ed. National Center for Asphalt technology(NCAT): 1996.

[14]Asphalt Institute, superpave performance graded asphalt binder specification and testing. Superpave Series no1(SP-1). Asphalt Institute, Lexington, KY, USA; 2003. P.61.

[15]Ghile DB. Effects of nanoclay modification or rheology of bitumen and on performance of asphalt mixtures. Delft, The Netherlands: Delft university of technology ; 2006.

[16]Liu D-L, Yao H-B, Bao S-Y. Performance of nano-calciumcarbonate and SBS compound modified asphalt. Zhongnan Daxue Xuebao (ziran kexue Ban)/J Central South Univ (Sci Technol)2007; 38(3):579-82.

[17]Ma F, Zhang C, Fu Z. Performance and modification mechanismof nano-caco3 modified asphalt. Wuhan Lingong Daxue Xuebao (Jiaotong Kexue Yu Gongcheng Ban)/J Wuh Univ Technol (Transport Sci Eng) 2007;31(1):88-91.

[18]Yu J et al. Effect of montmorillonite on properties of styrenebutadiene-styrene copolymer modified bitumen. Polym Eng Sci 2007;47 (9):1289-95.

[19]Yu J et al. Preparation and properties of montmorillonite modified asphalts. J Wuh Uni Technol 2007; 29(9):65-7.

[20]Yu J et al. Preparation and properties of montmorillonite modified asphalts. Mater Sci Eng A 2007; 447(1-2):233-8.

[21]Hussain F, Roy S, Narasimhan K, Vengadassalam K, Lu H. E-glass/ polypropylene pultruded nanocomposite: manufacture, characterization, thermal and mechanical properties. J Thermoplast Compos 2007; 20:411-34.

[22]Roy S, Hussain F, Narasimhan K, Vengadassalam K, Lu H. E-glass/ polypropylene nanocomposites: manufacture, characterization and mechanical properties. Polym Polym Compos 2007; 15(2):91-102.

[23]Ke Yc, Stroeve P. Polymer-layered silicate and silica nanocomposites. The Netherlands: Elsevier; 2005.

[24]Qian X, Liao M, Zhang W. Surface modification of montmorillonite and application to the preparation of polybutadiene/montmorillonite Nano composites. Polym Int 2007; 56(3):399-408. 